\title{
Isolation of a Coronavirus During Studies on Puffinosis, a Disease of the Manx Shearwater (Puffinus puffinus)
}

\author{
By \\ P. A. NutTall and K. A. Harrap \\ NERC Institute of Virology, Oxford, United Kingdom \\ With 4 Figures \\ Accepted April 23, 1982
}

\begin{abstract}
Summary
A virus was isolated from 2 day-old mice inoculated with homogenates of either the lungs or blood of 2 different shearwaters affected by puffinosis. Examination of infected suckling mouse brain and infected NCTC-1469 (mouse liver) cell cultures, by electron microscopy, revealed virus particles and inclusion bodies characteristic of a coronavirus. Neutralization, complement fixation and fluorescent antibody tests showed that the virus was related to mouse hepatitis virus. The virus was not isolated from 445 control, uninfected mice. Neutralising antibodies were not detected in 39 sera from diseased shearwaters and 2 sera from apparently healthy birds. Two shearwaters inoculated with the virus did not develop clinical signs of infection. The question of whether the virus was isolated from shearwaters or from laboratory mice is discussed.
\end{abstract}

\section{Introduction}

Puffinosis is a disease of the Manx shearwater, Puffinus $p$. puffinus. The disease affects shearwaters breeding on two islands, Skomer and Skokholm, off the south-west coast of Wales. The most common clinical sign of puffinosis is blisters on the webs of the feet $(5,6,11)$, although conjunctivitis and locking of the ankle joint of the legs (described as "extensor spasm" [5]) have also been observed (8).

MrLes and SToken (1948) isolated an infectious agent from blood and blister fluid of shearwaters suffering from puffinosis. The agent produced characteristic histological changes in the chorio-allantoic membrane of fertile hens' eggs, and blisters in ducklings and pigeons; filtration studies indicated that it was of the size order of a virus.

Although puffinosis affects shearwaters throughout their breeding season (Nuttall, P. A., Harrap, K. A., and Perrins, C. M.; unpublished observation), the disease is most apparent during late August and September when it occurs as an epizootic in fledglings; at least 75 per cent of affected birds die. We are studying puffinosis because, unlike many epizootics in wild animal populations, 
detailed investigation is possible owing to the regularity of puffinosis epizooties, and the accessibility of affected birds. This paper reports the isolation of a coronavirus during our attempts to determine what causes puffinosis.

\section{Materials and Methods}

\section{Cell Culture}

NCTC clone 1469 (mouse liver) cells were obtained from Flow Laboratories (Irvine, Scotland) and grown in NCTC 135 medium. Primary mouse macrophage cultures were established by inoculating freshly killed mice intra-peritoneally with 2 to $3 \mathrm{ml}$ of MEMAlpha medium (Gibeo Bio-cult Ltd., Paisley, Scotland), pummeling the body cavity, and then withdrawing the medium. Tho cells, suspended in the medium, were incubated in $25 \mathrm{~cm}^{2}$ flasks. Continuous cell lines of mouse macrophages $\left(\mathrm{P} 388 \mathrm{D}_{1}\right)$ and pig kidney PS clone D, were kindly supplied by Dr. J. S. Porterfield (Sir William Dunn School of Pathology, Oxford) and grown as described $(13,16$ respectively). Xenopus laevis and Aedes albopictus cell cultures were obtained from M. Pudney (London School of Hygiene and Tropical Medicine) and have been maintained in this laboratory for several years. Xenopus cell eultures were grown in Leibovitz's medium L-15 supplemented with 10 per cent tryptose phosphate broth, and Aedes cells in Mitsuhashi and Maramorosch medium. BHK cell cultures were grown in Eagle's medium (Glasgow modification) supplemented with 10 per cent tryptose phosphate broth, Vero and primary chick embryo fibroblasts (CEF) in Eagle's MEM. All cell cultures were grown at $37^{\circ} \mathrm{C}$ except Xenopus and Aedes which were grown at $28^{\circ} \mathrm{C}$, and all media were supplemented with 10 per cent heat-inactivated foetal calf serum (FCS). NCTC growth medium was supplemented with either 10 per cent FCS or 10 per cent horse serum.

\section{Isolation Procedure}

During 1978,19 shearwaters showing elinical signs of puffinosis were transported live to Oxford where they were decapitated and the blood, organs, and webs of each bird collected. The birds were coded as SH 78-1 to SH 78-19. Explant cultures were established from the organs by placing $1 \mathrm{~mm}^{3}$ tissue samples in $25 \mathrm{~cm}^{2}$ flasks, allowing them to stick to the flasks by leaving them at room temperature for 1 hour, then gently filling each flask with $5 \mathrm{ml}$ Eagle's MEM supplemented with 20 per cent FCS. The flasks were incubated at $37^{\circ} \mathrm{C}$ and the medium changed weekly. Some of these cultures were subsequently subcultured successfully several times. The rest of the material was stored at $-70^{\circ} \mathrm{C}$.

Homogenates of approximately 20 per cent $\mathrm{w} / \mathrm{v}$ in phosphate buffered saline containing 0.4 per cent bovine plasma albumin, $200 \mathrm{units} / \mathrm{ml}$ penicillin, $200 \mu \mathrm{g} / \mathrm{ml}$ streptomyein, $200 \mu \mathrm{g} / \mathrm{ml}$ kanamycin, and $200 \mathrm{units} / \mathrm{ml}$ myeostatin (PBSA), were prepared from organs, webs and blood clots. After clarification each homogenate was inoculated separately into 1 to 3 day-old mice, $0.01 \mathrm{ml}$ intra-cerebrally (i.c.) and $0.01 \mathrm{ml}$ subcutaneously (s.c.) for each mouse. Pathology Oxford (P.O.) mice were used, a strain originally obtained from Evans Animal Laboratory, Carshalton and, since 1953, random bred at the Sir William Dunn School of Pathology, Oxford, to form a closed colony. Mice showing clinical signs of infection or, when there was no evidence of infection by 10 days after inoculation, 2 mice from each litter, were decapitated and a 20 per cent $\mathrm{w} / \mathrm{v}$ homogenate in PBSA prepared from the brains. Each clarified homogenate was inoculated (i.e. and s.c.) into a fresh litter of mice and observed for clinical signs of infection. The homogenates of suckling mouse brain (SMB) and of shearwater tissues were also inoculated into 8 and 11 day-old fertile hens' eggs by the allantoic, amniotic and yolk sac routes, and onto the chorio-allantoic membrane, and into various cell cultures.

The isolated virus was titrated by plaque enumeration in NCTC cell cultures in Linbro plates (Flow Laboratories) with NCTC135 medium supplemented with 3 per cent FCS and 0.75 per cent w/v carboxymethyl cellulose (BDH Chemical Ltd., Poole). 


\section{Electron Microscopy}

One $\mathrm{mm}^{3}$ portions were removed from the cerebral cortex, cerebellum and mid-brain region of SMB; infected cells were pelleted at $200 \times \mathrm{g}$. Cell pellets and SMB were fixed in 2 per cent glutaraldehyde followed by 1 per cent osmic acid. $0.2 \mathrm{M}$ phosphate buffer, pH 7.2, was used as a diluent for the fixatives and for intermediate washes. Fixed cells were dehydrated in a graded series of ethanol followed by acetone, and embedded in Epikote. Sections were cut using a Reichert Ultracut Ultramicrotome, stained with lead citrate and uranyl acetate and examined on a Jeol $100 \mathrm{CX}$ electron microscope at $100 \mathrm{kV}$.

To produce virus for negative staining NCTC cell cultures grown in $80 \mathrm{~cm}^{2}$ flasks, (approximately $1 \times 10^{7}$ cells/flask) were inoculated with either the first NCTC-passage of SH 78-2 lung ( $2 \times 10^{3}$ PFU) or the fourth SMB-passage of SH 78-8 blood $\left(1 \times 10^{4} \mathrm{PFU}\right)$ and then incubated at $37^{\circ} \mathrm{C}$ in NCTC medium supplemented with 3 per cent horse serum. Two days after inoculation a sample of the medium was examined by EM and the rest of the medium stored at $-70^{\circ} \mathrm{C}$ and replaced by fresh medium. Four days after inoculation infected and uninfected cultures were frozen at $-70^{\circ} \mathrm{C}$. The cultures and media were thawed and subsequent procedures carried out at $4^{\circ} \mathrm{C}$. Forty $\mathrm{ml}$ of supernatant media, clarified by centrifugation at $3500 \times g$ for 30 minutes, were either pelleted at $73,500 \times g$ for 1 hour or reduced in volume 100 - to 400 -fold using Lyphogel (Gelman Instrument Company, Michigan, U.S.A.). Pellets were resuspended in $0.1 \mathrm{ml}$ of $0.2 \mathrm{M}$ phosphate buffer $\mathrm{pH}$ 7.2. Preparations were stained with either 2 per cent $(\mathrm{w} / \mathrm{v})$ potassium phosphotungstate $\mathrm{pH} 6.8,2$ or 0.5 per cent $(\mathrm{w} / \mathrm{v})$ uranyl acetate $\mathrm{pH} 4.4$, or 2 per cent $(w / v)$ lithium tungstate $p H$ 7.6. Some preparations were fixed by adding 2 per cent formal saline to the elarified supernatant meduim.

\section{Serological Tests}

Hyperimmune rabbit serum was prepared by intravenous inoculation of the ears with 4 weekly doses of $1 \mathrm{ml}$ of 20 per cent w/v SMB in PBS of either the fourth SMBpassage of SH78-2 luny or the third SMB-passage of SH 78-8 blood. Immune ascitic fluids (AF) were prepared as described (14) using Landschültz's strain of Ehrlich's ascites cells and the sixth SMB-passage of SH78-2 lung mixed with an equal volume of Freund's complete adjuvant. Antisera to mouse hepatitis virus (MHV) and infectious bronchitis virus (IBV) were kindly supplied by Drs. K. Apostolov and M. Chong (Royal Postgraduate Medical School Hammersmith Hospital, and Guy's Hospital Medical School, London). The MHV antisera had been prepared by intraperitoneal inoculation of Swiss White mice (CFLP strain) with inactivated $\left(56^{\circ} \mathrm{C}\right.$ for 30 minutes) virus (20 per cent mouse liver homogenate) emulsified in Freund's incomplete adjuvant, followed by 2 inoculations with live virus at intervals of 2 weeks; the sera were collected 10 days after the last inoculation Antisera to IBV were collected from Rhode Island Red fowl chronically infected with the " $T$ " strain of IBV (2).

Complement fixation tests were performed using a standard technique (9), with titres expressed as the 50 per cent end-point; antigens were prepared by sucrose-acetone extraction of SMB (3). Immunofluorescent antibody tests (IFAT) were performed by the indirect technique using fluorescein-conjugated rabbit anti-mouse IgG (Miles Laboratories Ltd., Slough). Neutralization tests were performed using the plaque reduction technique (16) in Linbro plates; equal volumes of virus $\left(4.3 \log _{10} \mathrm{PFU} / \mathrm{ml}\right.$ from infested NCTC cells, diluted to give approximately $20 \mathrm{PFU} /$ well) and 2 -fold. dilutions of either heat-inactivated serum or AF were allowed to react together for 1 hour at room temperature and then titrated in NCTC cells.

\section{Results}

\section{Virus Isolation Attempts}

Homogenized tissues from 22 diseased shearwaters (including blood from 3 birds released after capture) were inoculated separately into a total of 418 two 
day-old mice; two of 51 homogenates each produced clinical signs in one mouse which were reproducible on mouse-passage. The first apparent isolation was from the lungs of a full grown shearwater (SH78-2) captured on the night of 11th May, 1978. The bird was ataxic and had hot, inflammed webs which were abraded and bleeding, and bore many small blisters. Signs of "extensor spasm" were not evident but the bird appeared to be in respiratory distress, sneezing and shaking its head. Gross pathological lesions were not observed at autopsy. Inoculation of mice with homogenates prepared from the webs, blood, brain, kidney, liver, spleen and testes of SH78-2, and from the lungs of five other diseased shearwaters, did not produce clinical signs of infection in the mice.

The second apparent isolation was from the clotted blood of a shearwater fledgling (SH78-8) captured on the night of 28th August, 1978. The bird had two burst blisters on the webs of the feet; no other pathological lesions were apparent. Clinical signs were not produced when mice were inoculated with homogenates prepared from the kidneys, lungs and faeces of $\mathrm{SH} 78.8$, and from blood clots from 11 other diseased shearwaters.

Attempts to isolate viruses from diseased shearwaters by establishing explant cultures from the various organs of the birds, by inoculating cell cultures of either CEF, Vero, BHK, PS, shearwater explant cultures, Aedes albopictus or Xenopus laevis, and by inoculating fertile hens' eggs, were all unsuccessful. Moreover, virus was not observed in sections of the various organs of SH78-2 when examined by electron microscopy.

Virus was not isolated from 445 control mice: 247 approximately 2 day-old mice inoculated intracerebrally with either PBSA or PBS and albumin, and 198 inoculated with control, uninfected SMB passed up to six times in mice.

\section{Isolation and Passage of Virus in Mice}

SH 78-2 lung was inoculated into five 2 day-old mice. Two of the mice showed clinical signs two days after infection; one was paralysed. The rest of the litter did not show clinical signs of infection during an observation period of 21 consecutive days after inoculation. A homogenate prepared from the brain of the paralysed mouse was diluted 1:2 in PBSA and then inoculated into four 2 day-old mice. Two of the litter showed clinical signs four days after inoculation and a third, seven days after inoculation. None of a litter inoculated with the brain of the other sick mouse showed evidence of infection.

SH78.8 blood was inoculated into five 2 day-old mice. One mouse showed clinical signs 10 days after inoculation. Passage of the brain of this sick mouse produced evidence of infection in seven of 16 inoculated mice, four to eight days after inoculation.

Unsuccessful attempts were made to repeat these results by inoculating two day-old mice with SH 78-2 lung and SH 78-8 blood (both stored at 70 ${ }^{\circ} \mathrm{C}$ ) 7.5 months and 4.5 months respectively, after the original apparent isolations were made.

After five passes in SMB isolate SH-78.2 lung had a $\mathrm{LD}_{50}$ titre of $4.2 \log _{10} / \mathrm{ml}$ in 2 day-old mice and, after six passes, isolate SH78-8 blood had a $\mathrm{LD}_{50}$ titre of $3.0 \log _{10} / \mathrm{ml}$. Clinical signs of infection were evident three to four days after inoculation and were characterized, initially, by hyperactivity, the gait then becoming un-coordinated and the posture hunched, followed by loss of balance 
and, finally, tremors and paralysis. Autopsy did not reveal any gross pathological lesions except for occasional petechial lungs. The clinical signs shown by infected mice were not observed in control mice inoculated with either PBSA or with control, uninfected SMB. Attempts were not made to isolate virus from mice which did not show clinical signs after inoculation with infectious SMB.

The isolates retained their infectivity for mice after filtration through $0.22 \mu \mathrm{m}$ filters. Infectivity was lost after treatment of infected SMB with 50 per cent ether for three hours at $4^{\circ} \mathrm{C}$. All of 43 mice inoculated intracerebrally with approximately $3.0 \log _{10} \mathrm{LD}_{50}$ of either $\mathrm{SH} 78-2$ lung or SH78-8 blood showed evidence of infection whereas only 3 of 31 ( 10 per cent) mice inoculated subcutaneously with the same inocula showed clinical signs. Virus was not isolated from either the liver, spleen, heart or leg muscle of seven infected mice. However, the lungs of 2 out of 4 infected mice produced clinical signs when inoculated intracerebrally into 2 day-old mice, but virus was not isolated from the lungs of these mice. Five 3 week-old mice were inoculated intracerebrally with the sixth SMB-passage of SH78.2 lung but clinical signs of infection were not observed. Furthermore, evidence of infection was not observed in 2 day-old mice inoculated with the brains of these weanling mice (harvested 23 days after inoculation).

\section{Examination of Suckling Mouse Tissue by Electron Microscopy}

Inclusion bodies, 3 to $12.5 \mu$ in diameter, were observed in the mid-brain regions, but not in the cortex and cerebellum, of mice infected with either of the two isolates (Fig. 1). The inclusions contained variable numbers of electron dense particles, within a densely staining matrix which occasionally contained membranes (Fig. 1c). The majority of inclusions were membrane-bound although some particles were observed within an unbound matsix (Fig. 1 b). Inclusions were intra-cytoplasmic and frequently adjacent to a large nucleus, probably of a neuroglial cell (Figs. 1 a and $1 \mathrm{~b}$ ). Occasionally, inclusions were observed in areas of necrosis (Fig. 1a). Virus particles within the inclusions were either completely electron dense, showing a reticular structure, or had a "hollow" centre; some were surrounded by a closely adherent membrane. Particles were often seen near the outer edge of inclusions where the inclusion body membrane appeared convoluted (Fig. 1c). Individual virus particles were observed rarely and were usually surrounded by two membranes (Fig, 1d). Virus particles and inclusion bodies were not observed in the lungs of two infected mice, nor in the brains of 6 control mice inoculated with either PBSA or control, uninfected SMB passaged 5 times in mice. Moreover, such virus particles and inclusion bodies could not be found in the brains of 29 mice inoculated with tick homogenates during a study of tick-borne viruses of seabirds.

\section{Inoculation of Manx Shearwaters}

Four shearwater nestlings approximately 65 days old were collected from Skomer and transported to Oxford. Two birds were inoculated with the fifth SMBpassage of SH 78-2 lung, $0.1 \mathrm{ml}$ intradermally in the undersurface of the left foot, and $0.1 \mathrm{ml}$ by scarification of the undersurface of the right foot. The two remaining birds were inoculated similarly with PBSA. The birds were kept under observation for 23 days. One day after inoculation the scarified webs of the birds inoculated 

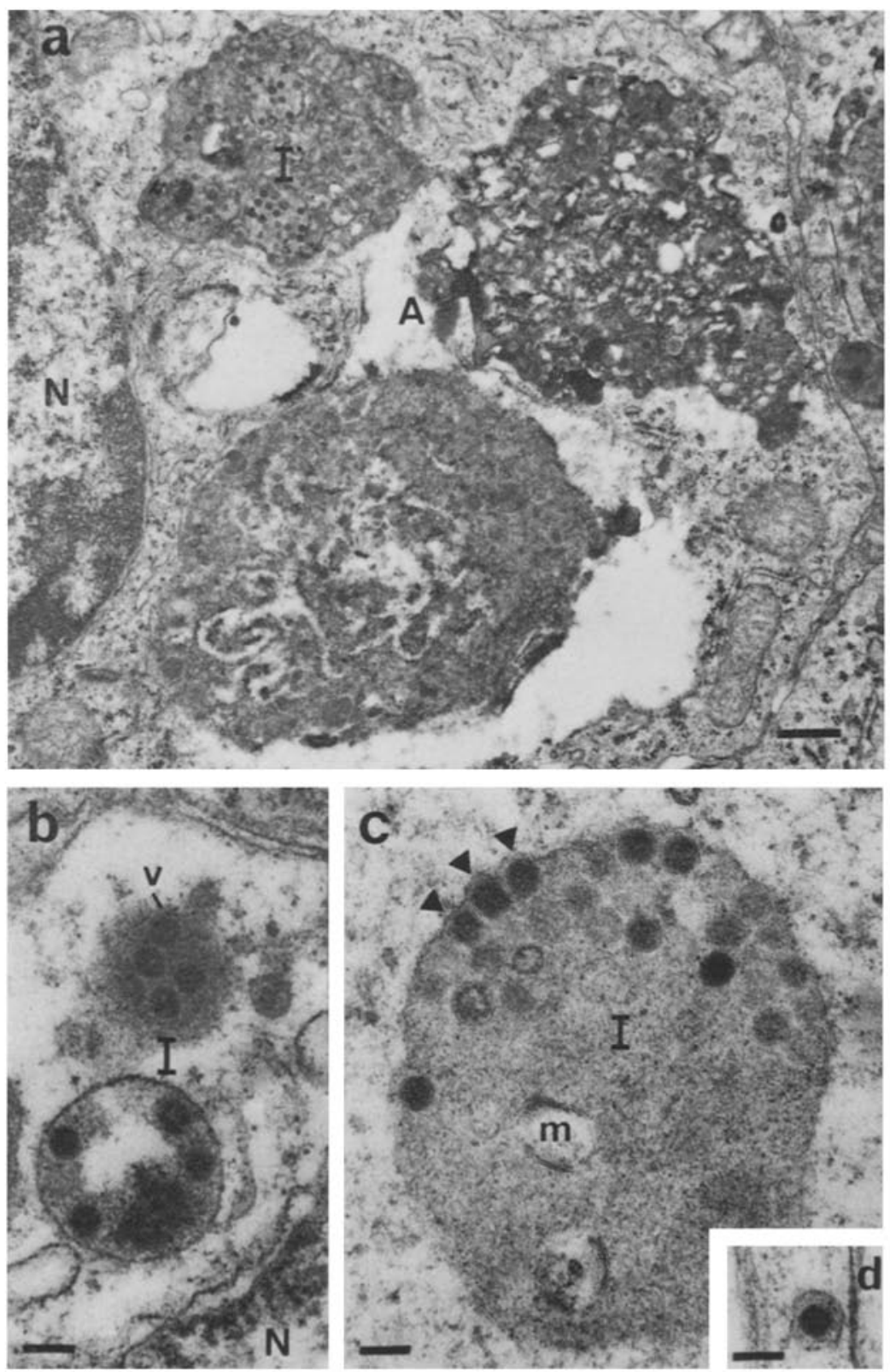

Fig. 1. Electron micrographs showing areas of the mid-brain of two day-old mice inoculated with eithor the fourth SMB-passage of SH78-8 blood (a), or the fifth SMBpassage of SH 78-2 lung $(b, c, d)$. Figs $1 \mathrm{a}, \mathrm{b}, \mathrm{c}$ show virus particles within inclusion bodies; $1 \mathrm{~d}$ shows a single virus particle surrounded by two membranes. $A$ area of necrosis ; $I$ inclusion; $m$ membranes; $N$ nucleus of neuroglial cell ; $v$ virus particle ; arrows indicate virus particles adjacent to protruding inclusion body membrane. Bar, $500 \mathrm{~nm}$

(a) and $100 \mathrm{~nm}(\mathrm{~b}, \mathrm{c}, \mathrm{d})$ 
with the virus were inflamed but blisters did not develop. The webs of the control birds appeared normal; one control bird died 3 days after inoculation. None of the birds showed gross pathological lesions when autopsied. Neutralising antibodies were not detected in sera from the shearwaters prior to inoculation. Owing to difficulties encountered in keeping the birds, sera were not collected after inoculation.

\section{Inoculation of Cell Cultures and Eggs}

The virus isolated in mice did not show evidence of replication in either fertile hens' eggs (inoculated by the various routes) or cell cultures of Vero, BHK, CEF,
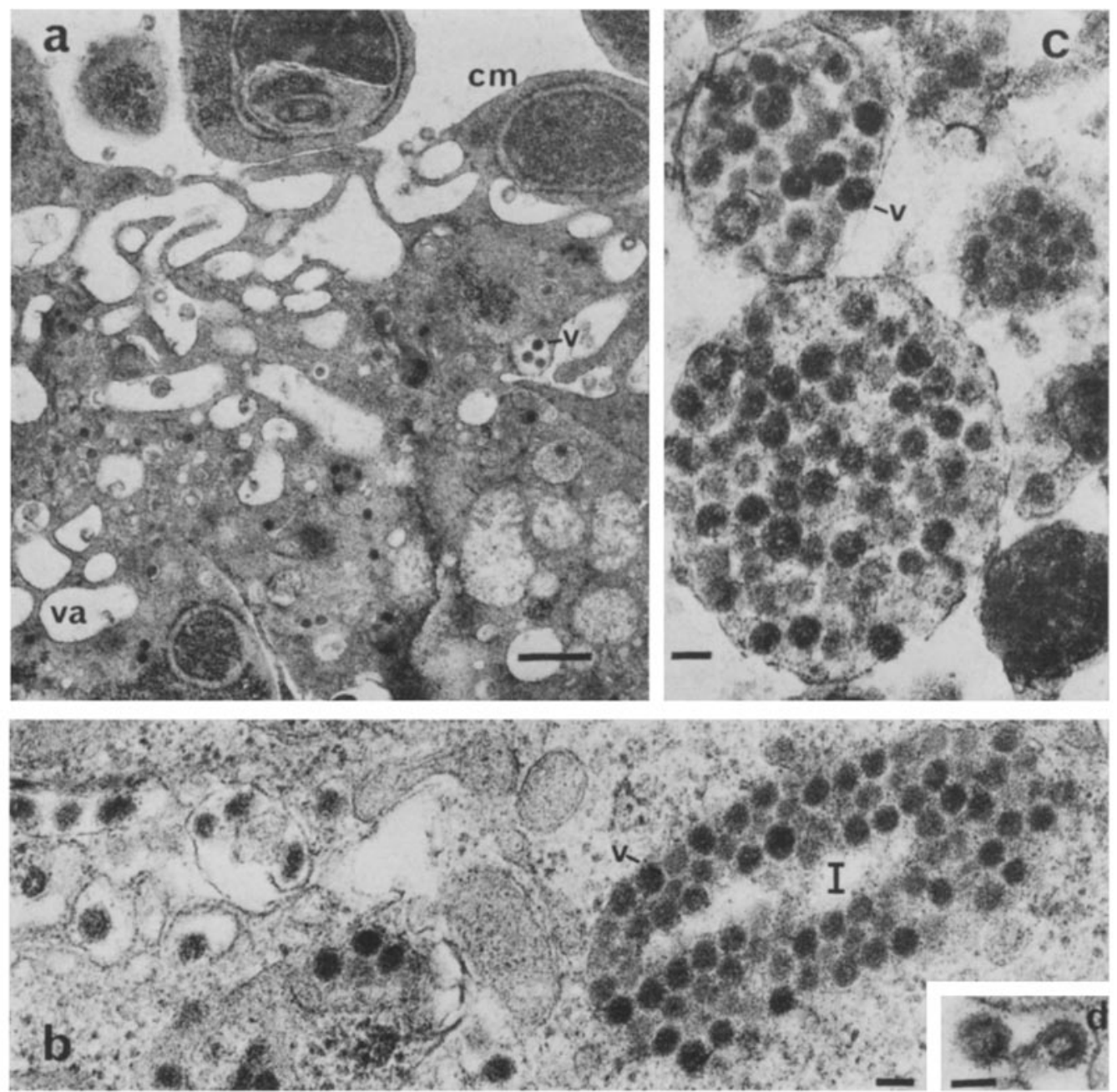

Fig. 2. Electron micrographs showing NCTC cell cultures two days ( $a$ and $b$ ) and four days (c) after infection with the fifth SMB-passage of SH78-2 lung. Figs. $2 a$ and $b$ show intracellular virus particles within inclusions $(I)$ and vacuoles $(v a)$, and the markedly convoluted cell membrane $(\mathrm{cm}) ; 2 \mathrm{c}$ shows extra-cellular virus particles in membrane-bound vesicles; $2 \mathrm{~d}$ shows endogenous C-type particles. Bar, $500 \mathrm{~nm}$ (a) and $100 \mathrm{~nm}(\mathrm{~b}, \mathrm{c}, \mathrm{d})$ 
PS, primary mouse macrophages, a continuous line of mouse macrophages, or shearwater web and lung explant cultures. However, large syneytia were produced in NCTC cell cultures two days after inoculation with the fifth SMB-passage of SH 78-2 lung; four days post infection (p.i.) the cells were completely detached and rounded. Passage of the virus in NCTC cells yielded $5.3 \log _{10}$ PFU/ml, two days after infection.

A cythopathic effect was not observed in NCTC cell cultures inoculated with SMB from 12 different suckling mice inoculated with either PBSA or control SMB.

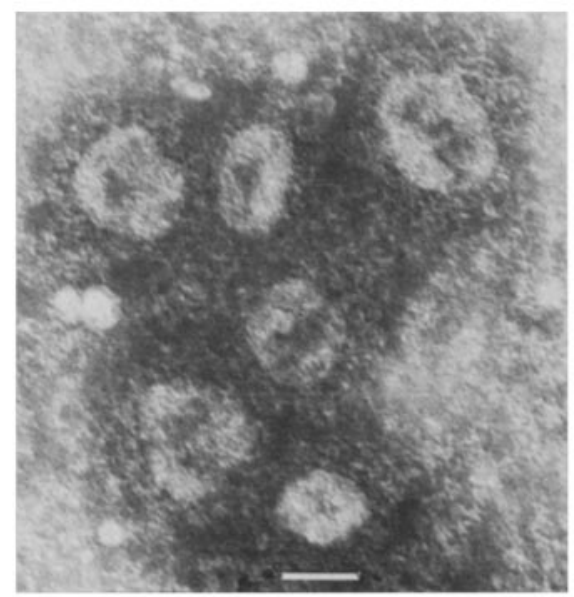

Fig. 3. Virus-like particles from infected NCTC cell eultures which were fixed with 2 per cent formal saline, concentrated 100-fold using Lyphogel, and then stained with

2 per cent $(\mathrm{w} / \mathrm{v})$ potassium phosphotungstate, $\mathrm{pH} 6.8 \mathrm{Bar}, 50 \mathrm{~nm}$

\section{Electron Microscopic Examination of Virus Grown in NCTC Cell Cultures}

Infected cells were examined 2 and 4 days p.i. when the virus titres were 4.3 and $3.0 \log _{10} \mathrm{PFU} / \mathrm{ml}$, respectively. Two days $\mathrm{p}$. $i$. the cells were vacuolated and the cell membrane convoluted; densely staining inclusions were observed in the cytoplasm (Figs. 2a and 2b). Electron dense virus particles were present in the inclusions and within the vacuoles. Four days p.i. infected cells were completely disrupted and the culture contained membrane-bound vesicles packed with virus particles (Fig. 2c). The particles had a reticular internal structure, and were membrane-bound; surface projections were not apparent. Similar virus particles and inclusions were not observed in either uninfected NCTC cell cultures or cultures inoculated separately with SMB from 18 control mice. Virus particles in infected cultures were readily distinguished from virus-like particles, resembling C-type particles, which were observed in control and infected cultures (Fig. 2d) and which were similar to virus-like particles previously seen in the NCTC1469 cell line (7).

Characteristic coronavirus particles were not observed in negatively stained preparations of infected NCTC cell cultures. Membrane-bound particles were observed in infected and not in uninfected NCTC cultures concentrated 100 -fold using Lyphogel, but they did not possess distinct surface projections (Fig. 3). 
Table 1. Complement fixation tests

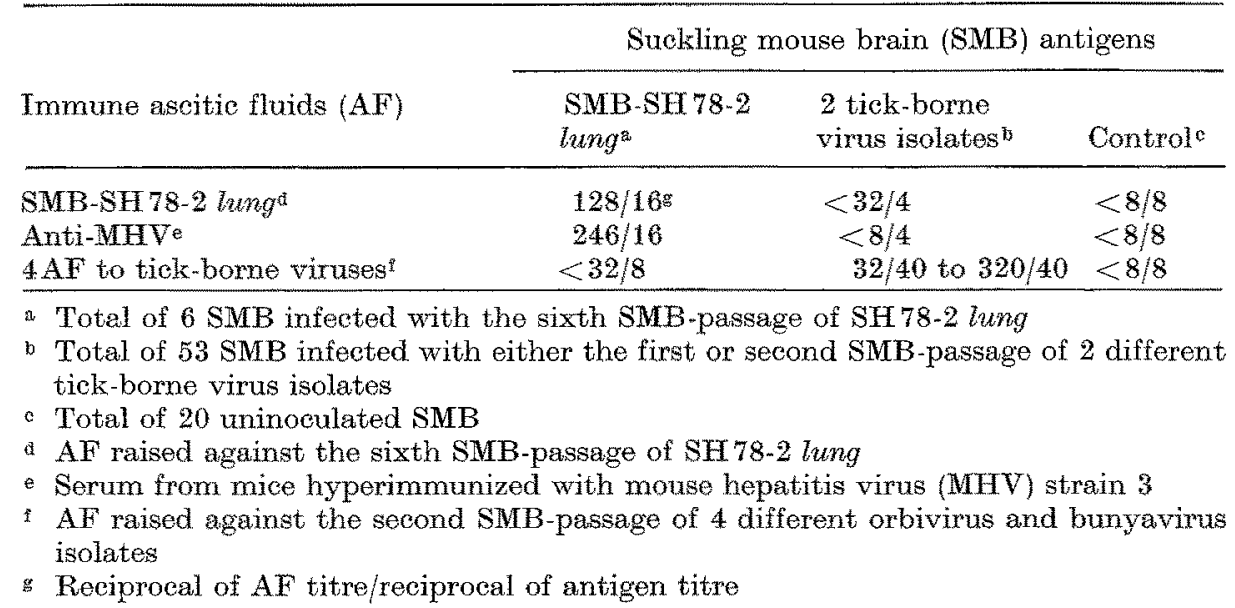

\section{Complement Fixation Tests}

Isolate SH 78-2 lung reacted with homologous $\mathrm{AF}$ and with antiserum to $\mathrm{MHV}$ strain 3 (Table 1). The antigen did not react with four different $\mathrm{AF}$ raised against: various SMB-grown orbiviruses and bunyaviruses. Both SH78-2 lung AF and MHV antisera did not react with either SMB infected with two different orbiviruses, or SVB from uninoculated mice.

Table 2. Neutratising antibody titres to SMB-passed SH 78-2 lung and SH-78-8 blood grown in NCTC cell cultures

\begin{tabular}{|c|c|}
\hline Serum or ascitic fluid & Neutralising titre \\
\hline Homologous antiserab & $<10$ \\
\hline Homologous ascitic fluid ${ }^{c}$ & 40 \\
\hline Heterologous ascitic fluids a & $<8,8,16$ \\
\hline Anti-MHVe & $960,>320$ \\
\hline Anti-IBVi & $<10$ \\
\hline $\begin{array}{l}2 \text { sera from healthy and } 22 \text { sera from diseased full-grown } \\
\text { shearwaters }\end{array}$ & $<8$ \\
\hline 17 sera from diseased juvenile shearwaters & $<8$ \\
\hline
\end{tabular}

a Reciprocal of the dilution of serum or ascitic fluid which produced a 50 per cent reduction in the number of plaques compared with control virus

b Sera from two rabbits, one hyperimmunized with the four SMB-passage of SH 78-2 lung, and the other with the third SMB-passage of SH 78-8 blood and the fifth SMBpassage of SH 78.2 lung

- Ascitic fluid from raice hyperimmunized with the sixth SMB-passage of SH78.2 lung

- Three aseitic fluids from mice hyperimmunized with three different SMB-grown orbiviruses

e Two sera from mice hyperimmunized with mouse hepatitis virus (MHV) strain 3; homologous neutralising titres $1 / 960$ and $1 / 640$ in suckling mice (Chong, $K$. T.: personal communication)

\& Two sera collected from Rhode Island red fowl chronically infected with the "Tr" strain of TBV (2) 


\section{Fluorescent Antibody Staining}

NCTC cell cultures grown on coverslips were stained by IFAT 24 hours after inoculation with $2 \times 10^{3}$ PFU of SH78-2 lung (fifth SMB-passage passed once in NCTC cells). Syncytia and small groups of cells fluoresced when treated with AF raised against either the sixth SMB-passage of SH78-2 lung, or 2 sera from mice hyperimmunized with MHV strain 3. Fluoreseence was not observed in infected cultures treated with 4 different AF raised in our laboratory against various orbiand bunyaviruses. Syncytia in which nuclei were clearly visible showed granular intracytoplasmic fluorescence (Fig. 4a). This became diffuse and more intense in syncytia which had rounded up (Fig. 4b).
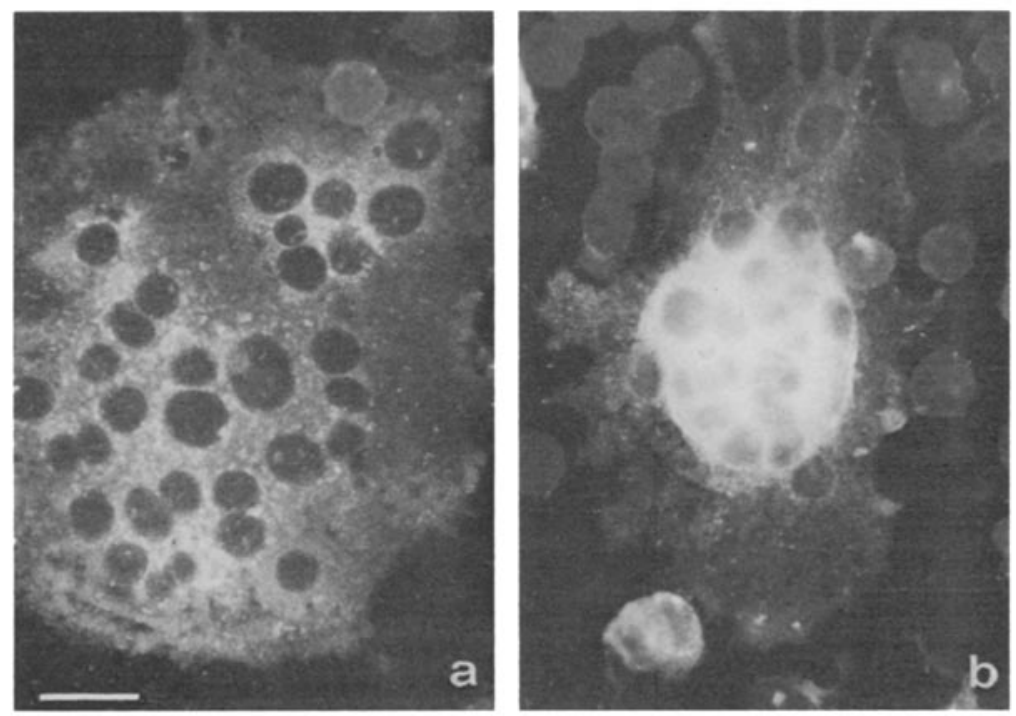

Fig. 4. NCTC cell cultures stained by IFAT with antiserum to mouse hepatitis virus type 3 and showing syncytia in the early $(a)$ and late (b) stages of infection. Bar, $3.2 \mu \mathrm{m}$

\section{Neutralization Tests}

Virus grown in NCTC cell cultures was neutralized by AF raised against the sixth SMB-passage of SH78-2 lung, but not by antisera from two rabbits hyperimmunized with the two isolates (Table 2). Neutralization also occurred with two antisera raised against MHV, but not with antisera to IBV. Low levels of neutralization were detected with two of three AF raised against three different SMBgrown orbiviruses. Sera from 22 full-grown shearwaters, 16 fledglings, and one chick, all of which showed clinical signs of puffinosis, and from two apparently healthy adult birds, did not neutralize the virus.

\section{Diseussion}

During attempts to isolate the causative agent of puffinosis, a virus was isolated from mice inoculated with homogenates of either the lungs or blood of two different shearwaters affected by puffinosis. Examination of infected SMB and 
infected NCTC cell cultures, by electron microscopy, revealed virus particles and inclusion bodies similar to those observed for several coronaviruses, including MHV (7), IBV (12), haemagglutinating encephalomyelitis virus of pigs (4), and human coronavirus strain $229 \mathrm{E}(10)$, although typical coronavirus particles (22) were not observed by negative staining. Neutralization tests, CFT, and IFAT showed that the virus was related to MHV. The results raise the question, was the virus isolated from Manx shearwaters or from laboratory mice?

The evidence for virus isolation from shearwaters was that the virus was only isolated from mice inoculated with shearwater material; repeated attempts to isolate a similar virus from control, uninfected mice were unsuccessful. Although the virus was not re-isolated from SH78-2 lung and SH78-8 blood, this may have been due to the low titre of the virus (together with loss of infectivity during storage) since, when the original isolations were made, virus was only isolated from one mouse in each litter.

The virus differed from the agent isolated previously (17) from diseased shearwaters in that it did not, apparently, replicate in fertile hens' eggs and was much larger. Filtration studies (21) indicated that this agent was 20 to $30 \mathrm{~nm}$ in diameter, although the reliability of filters used at that time may be questioned (Miles, personal communication).

The evidence indicating that the virus was isolated from mice was that it reacted with antisera raised against $\mathrm{MHV}$, and only replicated in suckling mice and in mouse cell culture. However, the virus differed from reported strains of MHV in that it did not appear to replicate in weanling mice, and was not detected in the livers of infected mice $(18,15)$.

MHV is serologically related to rat coronavirus, sialodacryoadenitis virus of rats, some human coronaviruses and possibly haemagglutinating encephalomyelitis virus of pigs (20). Antigenic relationships between MHV and avian coronaviruses (IBV and transmissible enteritis virus of turkeys) have not been demonstrated. If the virus was isolated from shearwaters it may represent a virus of rodents transmitted to shearwaters. This would explain its antigenic relationship with MHV.

The problems that arise in using mice for virus isolation are well illustrated by Tettnang virus, originally thought to have been isolated from man but now believed to be a strain of MHV $(19,1)$. Several similarities exist between Tettnang virus and the virus isolated during our work on puffinosis. Tettnang virus produced clinical signs 3 to 4 days after inoculation of 1 to 2 day-old mice, was more pathogenic via the intracerebral rather than subcutaneous routes of inoculation, and did not, apparently, affect older mice. However, 21 isolations of Tettnang virus were made, including several from mice inoculated with PBS and from uninoculated mice. In contrast, we were unable to isolate a virus from 445 control mice. Hyperimmune AF raised against 2 orbiviruses apparently showed slight neutralising activity with the isolated virus; however, cross-reactions were not detected by CFT. Attempts to isolate a coronavirus from the inocula used to produce these AF were unsuccessful.

The virus isolated in mice did not produce clinical signs of puffinosis when inoculated into Manx shearwaters. STOKER and MiLes (1953) were also unable to reproduce the disease in shearwaters but were able to demonstrate neutral- 
ization and complement fixation with sera from 2 shearwaters that had recovered from the disease. Our inability to detect antibodies in shearwater sera may have been due to the fact that the sera were collected from healthy and acutely-infected birds; convalescent sera were not available.

Attempts to detect a virus in laboratory mice similar to the virus isolated were unsuccessful. This suggests that the virus isolated was from shearwaters. However, the evidence is not conclusive owing to the frequency of infections of mouse colonies with MHV and the difficulties of detecting such infections. Comparative studies with MHV have not been carried out because we do not wish, knowingly, to introduce MHV to our mouse colony. We hope to conclude our studies on the isolated coronavirus by either increasing the number of isolations of this virus from shearwaters, or by proving that puffinosis is caused by some other infections agent.

\section{Acknowledgments}

The authors wish to thank J. Brockall, L. Moreton, D. Carey and J. Kirchoff for their assistance, and Dr. J. S. Porterfield for helpful discussions of the work.

\section{References}

1. BÁRdǒs, V., ScrwaNzer, V., PeŠKo, J.: Identification of Tettnang virus ("possible arbovirus") as mouse hepatitis virus. Intervirol. 18, 275-283 (1980).

2. Chong, K. T., Apostolov, K.: The pathogenesis of nephritis in chickens induced by infectious bronchitis virus. J. Comp. Path. (in press).

3. Clarke, D. H., Casals, J.: Techniques for haemagglutination and haemagglutination-inhibition with arthropod-borne viruses. Am. J. Trop. Med. Hyg. 7, $516-573(1958)$.

4. Clarke, J. K., McFerran, J. B.: An electron microscopic study of haemagglutinating encephalomyelitis virus of pigs. J. gen. Virol. 13, 339-344 (1971).

5. Dane, D. S.: A disease of Manx shearwaters (Puffinus puffinus). J. Anim. Ecol. 17, $158-164(1948)$.

6. Dane, D. S., MLles, J. A. R., Stoker, M. G. P.: A disease of Manx shearwaters: further observations in the field. J. Anim. Ecol, 22, 123-133 (1953).

7. David-Ferrema, J. F., Manaker, R. A.: An electron microscope study of the development of a mouse hepatitis virus in tissue culture cells. J. Cell Biol. 24, $57-78(1965)$.

8. Diamond, A. W.: Puffinosis among Manx shearwaters. Brit. Birds 59, $82-84$ (1966).

9. Grist, N. R., Belt, E. J., Folderti, E. A. C., Urquart, G. E. D.: Diagnostic methods in elinical virology. Oxford: Blackwell 1979.

10. Hamre, D., Kindig, D. A., Mans, J.: Growth and intracellular development of a new respiratory virus. J. Virol. 1, 810-816 (1967).

11. Hardrs, M. P.: Puffinosis among Manx shearwaters on Skokholm. Brit. Birds 58, $426-434(1965)$.

12. Hirai, K., Yagam, K., Shimlakura, S., Hmano, N., Taguchi, F., Suzumi, Y.: Growth of infectious bronchitis virus in suckling mice brain. Res. Bull. Fac. Agr. Gifu Univ. 39, 165-170 (1976).

13. Korex, H. S., HANDwerger, B. S., WUNDERLICH, J. R.: Identification of macrophage-like characteristics in a cultured murine tumour line. J. Immunol. 114, $894-897(1975)$.

14. Lennette, E. H., Schmidt, N. J.: Diagnostic procedures for viral, ricketisial, and chlamydial infections, ch. 26, 767-814. Washington D. C.: American Public Health Association, Ine. 1979. 
15. MoInrosin, K.: Coronaviruses: a comparative review. Curr. Top. Mierobiol. Immunol. 63, 85-129 (1974).

16. MAdrid, A. T. De, Porterfteld, J. S. : A simple micro-culture method for the study of group B arboviruses. Bull. W.H.O. 40, 113-121 (1969).

17. Mrues, J. A. R., Stoker, M. G. P.: Puffinosis, a virus epizootic of the Manx shearwater (Puffinus p. puffinus). Nature 161, 1016-1017 (1948).

18. PrazzA, M.: Experimental viral hepatitis. Springfield, Ml. : Ch. C Thomas 1969.

19. Rehse-KüpPer, B., Dannelová, V., Ackermann, R.: Isolierung eines für Mäuse pathogenen Virus aus Ixodes ricinus (L.) in Nordrhein-Westfalen und in Oberschwaben. Zentrbl. Bakt., I. Abt. Orig. A 244, 168-177 (1973).

20. Robr, J. A., Bond, C. W.: Coronaviridae. In: Fraenkel-Conrat, H., Wagner, R. R. (eds.), Newly Characterized Vertebrate Viruses (Comprehensive Virology, Vol. 14), 193-247. New York-London: Plenum Press 1979.

21. Stoker, M. G. P., MrLes, J. A. R. : Studies on the causative agent of an epizootic amongst Manx shearwaters (Puffinus p. puffinus). J. Hyg. 51, $195-202$ (1953).

22. Trrreld, D. A. J., Ammeida, J. D., Cunntmgham, C. H., Dowdle, W. R., Hofstad, M. S., McIntosh, K., Tajima, M., Zakstelskcaya, L. Ya., Easterday, B. C., Kaptkian, A., Bingham, R. W.: Coronaviridae. Intervirol. 5, 76-82 (1975).

Authors' address: Dr. P. A. NUTTaLt, NERC Institute of Virology, Mansfield Road, Oxford OX $13 \mathrm{SR}$, United Kingdom.

Received October 1, 1981 